\title{
Public Perceptions of Minorities in America: Political Correctness in U.S. History Textbooks, Before and After 1970
}

\author{
Chung Hyun Lee
}

\begin{abstract}
There have been various social movements throughout history to protect minorities from discrimination and infringements of their rights. However, as we can see from many historical cases, these movements are not direct representative of changes in public perceptions. This paper used political correctness as conveyed in textbooks - changes in the term referring to African Americans and increased reference to African American and female public figures - in order to demonstrate the actual impacts of these movements on public perceptions. The examined differences, which are the disappearance of the term negro and appearance of the term African-American, and increased mentioning of African-American and women public figures in text book, considering the fact that textbooks reflect value-sensitive publishing, indicate that public opinion regarding minorities changed after the active social movements of the 1960s and 70s.
\end{abstract}

Index Terms-Political correctness, minorities.

\section{INTRODUCTION}

A few years ago in South Korea, there was a controversy regarding the renaming of North Korean defectors. The center of the controversy was whether to include a term meaning "friends" in the official word, deemed as more politically correct; however, at the same time, this distinction was perceived as unnecessary. A few years ago, beyond the Korean context, there was also a growing opinion that the Canadian anthem, "O Canada," should be rewritten to make it more gender-sensitive. The grounds were that some parts of the lyrics, such as "True patriot love in all thy sons command," were gender discriminatory and thus politically incorrect [1].

The significance of such controversies is not whether they reach a resolution; it is the controversy itself. The fact that people actually care about the topic, and that it really matters to many people, shows that these topics are important issues for many societies.

'Political correctness' is becoming more important throughout the modern world, and it is becoming one of the main judging criteria for not only the content of public speeches and publications, but also in educational institutions Being politically correct is generally perceived as respecting the minorities (the exact definition of which is to be discussed in III. Definition). In other words, the phenomenon of political correctness and the increased attention paid to concomitant concerns might indicate that societies are becoming more sensitive to the rights of minorities.

Manuscript received August 10, 2013; revised September 21, 2013.

Chung Hyun Lee is with the Korean Minjok Leadership Academy, Republic of Korea (e-mail: sw021360@gmail.com).

\section{GOAL OF STUDY}

There have been various social movements throughout history and around the globe seeking to protect minorities from discrimination and infringements of their rights. However, as we can derive from many historical cases, the movements do not directly relate to change in public's perception. This paper examines the actual influences of these social movements on the perspectives of the general public. This paper is using the concept of political correctness as conveyed in textbooks in order to uncover changing perspectives, exploring the actual impacts of movements on public views. This approach stands in contrast to those that examine new legislations or court cases affected by these movements, as many books and research papers have previously emphasized.

\section{DEFINITION}

\section{A. Political Correctness}

There are two major theories on the origin of the term 'political correctness.' The first theory is that it is closely associated with Communist doctrine. According to Doris Lessing ${ }^{1}$, Communist doctrine was concerned not only with "doing the right thing," but also "thinking the right thoughts." Also, in one of Mao's edicts (Dec. 1929), Mao scolds "the failure of the Party's leading bodies to wage a concerted and determined struggle against the incorrect ideas and to educate the members in the Party's correct line." Later analysis of the phrase by Trotsky influenced the development of a notion of "a correct political perspective"[2]. ${ }^{2}$ Such facts support the idea that the concept of 'political correctness' derived from the Chinese Communists' "correct political lineism" Also, a process of translating an adjective in Mao's Little Red Book, which is a collection of his quotations, is supposed to have influenced the formation of the term [3]. However, Communist doctrine did not directly influence the term, because in the doctrine and the books written by Communists, "correctness" was only used as a word to mean something that is abiding by Communism or Maoism.

Another theory is that the term was coined by the American New Left in the 1970s, according to American linguist Robin Rakoff. They created the term as a sarcastic expression for the people who abide by the doctrine of their party without skepticism. In order to differentiate themselves from the Old Leftists, they used the term to convey their

${ }^{1}$ Doris Lessing is a British novelist. He published an article regarding the origins of Political Correctness in <Sunday Times> May $10^{\text {th }}, 1992$

${ }^{2}$ It was written in his book 'Problems of the Chinese Revolution' 
flexible and utopian ideals. They also used the term "politically incorrect" as well. However, as the Right adopted the word as a way to differentiate them from and to attack the New Left, and as the term came to be widely used, it changed from sarcasm to slandering.

In 1977, political correctness was formally defined as 'conformity to a body of liberal or radical opinion on social matters, characterized by the advocacy of approved views and the rejection of language and behavior considered discriminatory or offensive' according to the Oxford Dictionary, one of the earliest dictionaries to officially include the term. However, the definition was later changed to 'The avoidance of forms of expression or action that are perceived to exclude, marginalize or insult groups of people who are socially disadvantaged or discriminated against' [4]. The recent definition excludes the idea that the term is conforming to the ideas of liberal or radical political opinions.

\section{B. Minority}

There are two major perspectives in defining the word "minority.' First, demographically, a minority refers to a group of people with numerical and population disadvantage in a society. In the social sciences, however, the term is used to refer to "categories of persons who hold few positions of social power" [5]. According to the Encyclopedia Britannica, minority specifically means "a culturally, ethnically, or racially distinct group that coexists with but is subordinate to a more dominant group. As the term is used in the social sciences, this subordinancy is the chief defining characteristic of a minority group" [6]. This paper uses the definition of minorities supported in the field of history.

\section{SCOPE OF STUDY}

The United States of America is usually referred to as a 'melting pot' consisting of diverse ethnic and racial groups. Thus, the issues of minorities have been, and still are, the main controversy and focus of various diverse social movements [7]. Also, with its superior influence across international society and the global notion of America as being the arsenal of democracy, many social movements and changes in America have influenced those of other countries as well.

The 1960s are a decade during which a number of interrelated cultural and political trends throughout the world coalesced. Specifically, the 1960s in America are sometimes denoted as 'the stormy sixties,' since it brought a sexual revolution, an active civil rights revolution, and an emergence of a 'counter culture [8]. Usually, the term 'the sixties' tends to include the early 1970 s, when referring to this time as an era of active social movements, since social movements were active throughout both decades [9]. This paper consequently examines the status differences of minorities before and after the social movements of the 1960s and 1970s. There are many groups of minorities in American society, but this paper will focus on two groups - African Americans and women - whose movements against discrimination had long been active, for nearly a century, during this era.

\section{METHOd OF STUdY}

Politically correct words have never been publically established by an institution or an organization. There has not been any one salient figure in the movement to promote political correctness - in fact, some advocates of political correctness oppose describing the trend as a movement at all. [3] The early supporters of political correctness focused first on changing the words or terms that referred to specific groups and, second, focused on acknowledging the cultural accomplishments of these minorities, for example, by citing relevant authors or artists in books [3]. This paper thus analyzes the specific words and terms used both when describing the minorities as well as the names mentioned when dedicating a social accomplishment of a particular group.

Textbooks are professional accounts of a subject, written and revised by experts of the field and are, in others words, of high credibility. Also, considering the fact that textbooks are used as a means to educate students at myriad institutions, and are chosen by the educators themselves, textbooks are greatly sensitive to the values of that current society. ${ }^{3}$ In this sense, this paper examines the use of politically correct language in U.S. history textbooks. In order to preclude any unexpected inconsistency, one type of textbook with different editions published in different years was chosen: American History: A Survey, published by McGraw-Hill. This paper analyzes the changes in the contents of the $1^{\text {st }}$ edition of the book, published in 1961 [10], the $6^{\text {th }}$ edition, published in 1979 [11], and the $9^{\text {th }}$ edition, published in 1997 $[12] .^{4}$

\section{AFRICAN AMERICANS}

\section{A. Usage of the Terms to Describe African Americans}

\section{1) The history of the terms}

'Nigger' or 'Negro' had been the predominant terms used to depict African Americans before advocates of political correctness demanded change. In the past, 'Negro' conveyed an implicit meaning of slave, as demonstrated in Francis Grose's slang dictionary (1785): "negro is figuratively used for a slave." [13] Later on, these words were readily used as insults, dating from about 1800, and were included in such phrases as "nigger hunts, ${ }^{5}$ and 'nigger luck. ${ }^{6}$ Even though the origin of the term Negro was a Spanish term for the color black, Negro is deemed as a symbol of slavery. Along with 'Negro,' 'Blacks' was widely used to describe African Americans, dating back from the $16^{\text {th }}$ century. 'Blacks' also originated from the color black but, as the word black achieved negative connotations of "evil, wicked, portentous, and malign" [3], social movements to avoid the usage of

\footnotetext{
${ }^{3}$ Such is supported by the speech-codes of the publishers. For example, McGraw-Hill had a speech code which included a phrase that the books published should follow the code of political correctness.

${ }^{4}$ In this paper, from now on, $1^{\text {st }}$ edition will refer to the American history: A survey published by McGraw-Hill published in $1961,6^{\text {th }}$ edition to American history: A survey published by McGraw-Hill published in 1979, and $9^{\text {th }}$ edition to the same book published in 1997

${ }^{5}$ Nigger hunts mean a search for a runaway slave, which evokes a similar image as with animal hunting.

${ }^{6}$ Nigger luck means an impossible luck, which infers that a Negro having luck is impossible.
} 
'Black' arose later as well. However, according to a recent survey, African Americans tend to prefer the term 'Black' more than 'African American' [3].

The alternative 'African Americans' phrasing as suggested by political correctness advocates was first suggested by the Black rights activists of the 1850s. The terms 'Negro' and 'Black' were too deeply related with slavery, reminding the users of these words of the discrimination faced by this group.

\section{2) Analysis of the books}

In the $1^{\text {st }}$ edition of American History, the term 'Negro' is used to refer to all African Americans interchangeably with African American 'slaves.' For example: "[the American Colonization Society] aimed to "colonize' freed Negroes in their homeland" (p. 313); "In the North, where there was wide-spread anti-Negro if not proslavery feeling" (p. 315); "Any person showing a strain of Negro ancestry was presumed to be a slave unless he could prove otherwise" ( $p$. 327); and, "Thus the majority of Northerners, though not necessarily for love of the Negro, eventually came to sympathize in varying degrees with the antislavery cause" (p. 333) [10].

However, in the $6^{\text {th }}$ edition, no usage of 'Negro' can be found anywhere in the book. Instead, the book used the word 'black' and 'slave' to describe African Americans. For example: "Between the blacks and whites of such a household, there might develop an affectionate, almost familial relationship" (p. 342); "But it is clear that the vast majority of Southern blacks were not content with being slaves, as they yearned for freedom even though most realized there was little they could do to secure it" (p. 343); and, 'The liberated blacks would then be transported out of the country and helped to establish a new society of their own" (p. 366) [11].

By the $9^{\text {th }}$ edition, the term 'African Americans' is used with the term 'blacks' to address the demographic group. For example: "As a result, African Americans under slavery began to develop a society and culture of their own, one in many ways unrelated to the white civilization around them" (p. 315); "Some blacks lived in almost prisonlike conditions, rigidly and harshly controlled by their masters" (p. 316); "Considering the odds confronting them, therefore, African Americans had reason for pride in the gains they were able to make during Reconstruction" (p. 434); and, "Freed from slavery, blacks throughout the South began almost immediately to create autonomous African-American communities" (p. 415) [12].

The change in the terms used to describe African Americans, the disappearance of 'Negro,' and the appearance of 'African American,' show how much political correctness became an accepted practice over time. The change in terms also reflects a change in public opinion in trying to avoid discrimination, and greater support for the rights of minorities, in this case, for African Americans.

\section{B. Inclusion of African American Public Figures}

\section{1) Frederick Douglass}

Frederick Douglass was a prominent African American writer in the 1800s. After escaping from slavery, he taught himself to read and write, and published vivid descriptions of the cruel slavery in the South. His autobiography, The Life of

\section{Frederick Douglass, was widely read. [15]}

The $1^{\text {st }}$ edition of American History does not mention Frederick Douglass at all. However, the $6^{\text {th }}$ edition introduces Douglass as "one of the most electrifying orators of his time, black or white," and "The most prominent black American of the pre-Civil War era, and indeed of the nineteenth century" (p.368) [11]. The $9^{\text {th }}$ edition explains Douglass and his impacts on the society similarly, but refers to him more frequently in the book - the $6^{\text {th }}$ edition refers to him on pages 368,369 , and 404 , but the $9^{\text {th }}$ edition makes references on pages $344,345,375$, and 412[12], and greater detail.

The inclusion of Douglass in the textbook's later editions signifies a change in perceptions of the role of African Americans in the broader society. By mentioning a prominent African American figure as a significant contributor of the social atmosphere of that era, the textbook is implicitly attributing an equal social role to the minority group, showing the growing social status of African Americans.

\section{2) Harriet Tubman}

Harriet Tubman was a runaway slave from Maryland, who eagerly helped the escape of other slaves into the abolitionist Free states by guiding them through the Underground Railroad - a network of abolitionists that protected and helped fugitive slaves. She helped the escape of nearly 300 slaves and was sometimes called "Moses" [14]. She is considered a remarkably active figure in the slave liberation movement.

In the $1^{\text {st }}$ edition of the American History, however, there is no mention of Tubman, either. 'The Underground Rail Road' is mentioned, but not Tubman, specifically. Also, even in the $6^{\text {th }}$ edition of the book, Tubman was still not mentioned. By the $9^{\text {th }}$ edition, Harriet Tubman finally appears as a prominent figure in slave resistance. The book explains that she had "assisted first members of her own family and then up to 300 other slaves to escape from Maryland to freedom" (p. 321) [13].

Tubman being cited as one of the major social activists, and the fact that the Black abolitionist movement was scrutinized and dealt with in greater detail, shows that African Americans were increasingly considered an equally important group in society.

\section{Inclusion of the Harlem Renaissance}

The Harlem Renaissance was "a cultural movement that spanned the 1920s, usually by African Americans. Many prominent artists, musicians and writers gained popularity at that time" [16].

Again, the $1^{\text {st }}$ edition of the textbook does not address the Harlem Renaissance at all. However, the $6^{\text {th }}$ edition mentions it in some detail: "In New York City, a new generation of black intellectuals created a flourishing Afro-American culture widely described as an artist" (p. 723) [11]. Artists such as Langston Hughes, James Weldon Johnson, Countee Cullen, Claude McKay, and Alain Locke were mentioned as well. The $9^{\text {th }}$ edition also similarly explains the Harlem Renaissance, with similarly detailed focus.

Acknowledging the African Americans as major contributors to society, along with acknowledging specifically influential individuals, reflects important societal changes. Especially given that the Harlem Renaissance was 
initially omitted despite its significance, its eventual, meaningful inclusion signifies growing social respect for African Americans.

\section{1) Interpretation}

Avoiding use of discriminatory terms that are affiliated with the history of prejudice and discrimination is one way to respect minorities. Increased inclusion of African American public figures and attribution of cultural significance to the group also shows an increased respect for the minority group by the general public. Such changes coincide with the changes sought by the social movements of the 1960s and 1970 s, such as the movements for equal rights and nondiscrimination.

\section{WOMEN}

\section{A. Inclusion of Women Public Figures}

\section{1) Jane Addams}

Jane Addams was engaged in providing settlement houses for the poor. As one of the early graduates of a women's seminary, she eventually established a settlement house for people in urban areas called the Hull House, which was the most prominent settlement house in America in the $20^{\text {th }}$ century. [17]. She received a Nobel Peace Prize in 1931 for her endeavors in civic responsibility. She was also a supporter of feminism, and women's suffrage [18].

Addams is an example of a female actively participating and contributing for the development of the society. Despite her significance, the $1^{\text {st }}$ edition of American History doesn't highlight Addams The textbook notes that, "Social workers established settlement houses in the foreign colonies to entice the aliens from the saloons and streets and bring them under religious influences. The most famous of the houses... [included] Hull-House in Chicago, directed by Jane Addams" (p. 507) [10].

However, the $6^{\text {th }}$ and the $9^{\text {th }}$ editions both draw more focus to the impacts and the importance of both Hull House and Addams, herself. The $6^{\text {th }}$ edition, upon introducing the Hull Houses founded by Addams, elaborates that the Hull Houses had "exposed another major change in progressive society; the expanding role of women" (p. 623) [11]. Also, the book adds that Addams and the Hull Houses had "helped to spawn another important institutions of reform: the profession of social work" (p. 623) [11]. The $9^{\text {th }}$ edition emphasizes the Hull Houses and Addams to a similar extent [12].

\section{2) Margaret Sanger}

Margaret Sanger was an activist and a social reformer. She fervently supported birth control in the U.S., along with the usage of contraceptives, and had spent her whole life fighting for the right to birth control. She also started a campaign in 1923 to support the Equal Rights Amendment to the Constitution. She had to flee the country due to the obscenity law in 1915, but she returned in 1916 and opened the first birth control clinic in U.S. [19]. Sanger was a controversial but fervent supporter of women's rights.

Despite her influence, the $1^{\text {st }}$ edition of American History fails to mention Sanger. In the $6^{\text {th }}$ edition, Sanger is mentioned in passing: "The 1920s saw the emergence of a national birth control movement, pioneered by Margaret
Sanger. Women should, Sanger argued, be free to enjoy the pleasures of sexual activity without relation to the bearing of children" (p. 717) [11]. The $9^{\text {th }}$ edition explains Sanger in greater detail, as well as the importance of her movement. The text explains Sanger's brief life in a paragraph starting with: "Sanger began her career promoting the diaphragm and other birth-control devices out of a concern for working-class women... Birth-control devices began to find a large market among middle-class women" (p. 660) [12]. Also, the importance of the movement is discussed, as 'Progress in the development of birth control was both a cause and a result of this change (liberalization of women and their thoughts)" (p. 660), and "The new, more secular view of womanhood had effects on women beyond the middle class as well" (p. 660) [12].

\section{3) Factory girls' association}

Lowell Mills, a textile manufacturing factory which was founded in 1821, was a factory famous for its system - the factory mainly employed unmarried girls from nearby rural areas. [8] The company was on its decline in the 1830s and 40 s when the number of textile manufacturing companies increased, and ended up cutting wages of its employees. The employees of the Lowell Mills, widely known as 'the factory girls' formed a union which not only participated in wage negotiations but moved on to work for better treatment of female workers working in the mills.[20] The Factory Girls' Association can be viewed as an active participation of the female workers of that era to better the labor system of the the society.

The $1^{\text {st }}$ edition of the book falls short of mentioning such labor movements, only mentioning that the Lowell girls, the workers of the Lowell Mills, worked in better conditions compared to female works in Britain, as in "Labor conditions in American mills seemed very good in comparison with conditions in English factories and mines"(p.291).[10] The explanation provided by the $6^{\text {th }}$ edition is not of a big difference, except the part where the book mentions 'expected difficulties of the workers' in the lines "Yet even these relatively privileged workers often found the transition from farm life to factory work difficult, ...that they now had to spend those days performing tedious, unvarying chores, and that their schedules did not change from week to week or season to season, made the adjustment to factory work a painful one."(p.268)[11]

The Factory Girls Association is finally mentioned in the $9^{\text {th }}$ edition of the book, including the fact that the organization later managed to develop into a bigger group named the Female Labor Reform Association. By stating "The new association (the Female Labor Reform Association) not only made demands of management; it turned to state government and asked for legislative investigation of conditions in the mills."(p.286)[12], the $9^{\text {th }}$ edition of the book explains more thoroughly the importance and impact of the organization started originally by the female workers of the Lowell Mills.

\section{4) Interpretation}

Like African Americans, women's developed public perception is largely symbolized by the increased number of within-group figures included in the book. By recognizing active women activists and supporters of social movementsboth individuals and association - it is not only parallel to the 
arguments of the supporters of political correctness that more females should be included in various fields in the history, but also cements the notion that women were as active and passionate as men in contributing to the betterment of society. Such change in perception, visible through the examination of the series of textbooks, reflects the very goals of the feminist movements of the 1960 s and early 1970 s.

\section{CONCLUSION}

This paper's goal was to examine the social changes, especially in the perspective of the public, aroused by the social movements in the U.S. during the 1960s and 1970s, through the lens of political correctness as portrayed in U.S. history textbooks. This paper dealt with two minority groups: African Americans and women.

As illustrated in the analysis of these books, the changes in the preferred term for referring to African Americans - Negro to African American - and the increased reference to African American historical figures reflect noticeable changes throughout the three compared editions. Also, the increased number and more detailed descriptions of female public figures and female association were an explicit trend throughout the three editions.

The change of the textbooks' contents reflects the trend suggested by the supporters of political correctness, who wanted to avoid discrimination against minorities. Considering the fact that these textbooks are mostly value-sensitive, there exists significant evidence that public opinion regarding minority groups changed after the active social movements of the 1960s and 1970s.

\section{REFERENCES}

[1] Spak, Kevin. (March 4, 2010). Canada Considers Anthem Edit. [Online]. Available: http://www.newser.com/story/82448/canada-considers-anthem-edit.ht $\mathrm{ml}$

[2] The Chinese Revolution and Theses of Comrade Stalin. [Online]. Available: http://www.marxists.org/archive/trotsky/1932/pcr/01.htm

[3] G. Hughes. Political Correctness: A History of Semantics and Culture, West Sussex: Wiley-Black Well, 2010

[4] Oxford On-Line Dictionary, 2011
[5] Wikipedia entry: Minority. [Online]. Available: http://en.wikipedia.org/wiki/Minority_group

[6] Encyclopedia Britannica entry: Minority. [Online]. Available: http://www.britannica.com/EBchecked/topic/384500/minority

[7] R. Hofstadter, The American Political Tradition and the Men Who Made It, New York: Vintage, 1989.

[8] D. M. Kennedy and L. Cohen, The American Pageant, United States: Wadsworth, 2013.

[9] Wikipedia entry: 1960s. [Online]. Available: http://en.wikipedia.org/wiki/1960s\#cite_note-Barth84Exhaustion-2

[10] N. C. Current and T. H. William, American History: A Survey, New York: McGraw-Hill, 1st edition 1961.

[11] N. C. Current and T. H. William, American History: A Survey, New York: McGraw-Hill, 6th edition, 1979.

[12] N. C. Current and T. H. William. American History: A Survey, New York: McGraw-Hill, 9th edition, 1997.

[13] G. J. Park. Political Correctness, Seoul: Communication Books, 2012, pp. 34.

[14] G. J. Park. Political Correctness, Seoul: Communication Books, 2012, pp. 193.

[15] Frederick Douglass Timeline. [Online]. Available: http://memory.loc.gov/ammem/doughtml/timeline.html

[16] Encyclopedia Britannica entry: Harlem Renaissance. [Online]. Available:

http://www.britannica.com/EBchecked/topic/255397/Harlem-Renaiss ance

[17] M. Schlesinger, Catton, B. Woodward, and Stampp, The National Experience: A History of the United States, United States: Harcourt Brace Jovanovich College Publishers, 1993.

[18] Nobel prizes and laureates: Jane Addams. [Online]. Available: http://www.nobelprize.org/nobel_prizes/peace/laureates/1931/addams -bio.html

[19] Biography of Margaret Sanger. [Online]. Available: http://www.biography.com/people/margaret-sanger-9471186

[20] I Cannot Be a Slave: Voices of the Lowell Mill Girls \& the Turn-Out of 1836. [Online]. Available: http://www.pbubuilder.org/PBUFiles/320/Student/millgirls_v2p2_200 90317041758/millgirls_v2p2/LevineProcess4.html

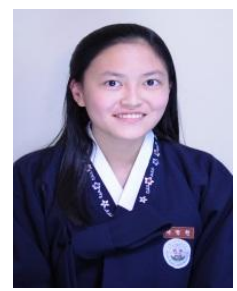

Chung Hyun Lee was born in Seoul, Korea and grew up in GwangJu, Korea. She is currently a student at Korean Minjok Leadership Academy. She has been exploring diverse activities and fields of studies, and has developed a special interest in educational policies, which she hopes to study further at university. She has been actively conducting research and writing research papers in these fields of interest, including "Suggestion of a cooperative vision for three Northeast Asian countries, through the expansion of educational policy and opportunity." 